\title{
Correction to: The microbiome as a biosensor: functional profiles elucidate hidden stress in hosts
}

\author{
Avihai Zolti ${ }^{1,2}$, Stefan J. Green ${ }^{3}$, Noa Sela ${ }^{2}$, Yitzhak Hadar ${ }^{1}$ and Dror Minz ${ }^{2 *}$
}

Correction to: Microbiome 8, 71 (2020)

https://doi.org/10.1186/s40168-020-00850-9

Following publication of the original article [1], an error was identified in the Fig. 7 legend.

The updated change has been highlighted in bold typeface.

The legend currently reads:

"Conceptual model of hypothetical bacteria harboring physiological features (i.e., genes, pathways and modules) associated with water quality. Features enriched in a TWW- or b FW-irrigated root microbiomes. White symbols indicate features that are significantly enriched at the DNA level (metagenomes), grey features are highly expressed (metatranscriptomes), and green features are significantly abundant and expressed in one treatment relative to the other".

The legend should read:

"Conceptual model of hypothetical bacteria harboring physiological features (i.e., genes, pathways and modules) associated with water quality. Features enriched in a FW- or b TWW-irrigated root microbiomes. White symbols indicate features that are significantly enriched at the DNA level (metagenomes), grey features are highly expressed (metatranscriptomes), and green features are significantly abundant and expressed in one treatment relative to the other".
Author details

${ }^{1}$ Department of Plant Pathology and Microbiology, Robert H. Smith Faculty of Agriculture, Food and Environment, The Hebrew University of Jerusalem, 76100 Rehovot, Israel. ${ }^{2}$ Institute of Soil, Water and Environmental Sciences, Agricultural Research Organization-Volcani Center, 7528809 Rishon Lezion, Israel. ${ }^{3}$ Sequencing Core, Research Resources Center, University of Illinois at Chicago, Chicago, IL, USA.

Published online: 30 June 2020

\section{Reference}

1. Zolti A, Green SJ, Sela N, Hadar Y, Minz D. F. Microbiome. 2020;8:71 https:// doi.org/10.1186/s40168-020-00850-9.

The original article can be found online at https://doi.org/10.1186/s40168020-00850-9.

* Correspondence: minz@volcani.agri.gov.il

${ }^{2}$ Institute of Soil, Water and Environmental Sciences, Agricultural Research

Organization-Volcani Center, 7528809 Rishon Lezion, Israel

Full list of author information is available at the end of the article

C C The Author(s). 2020 Open Access This article is licensed under a Creative Commons Attribution 4.0 International License, which permits use, sharing, adaptation, distribution and reproduction in any medium or format, as long as you give appropriate credit to the original author(s) and the source, provide a link to the Creative Commons licence, and indicate if changes were made. The images or other third party material in this article are included in the article's Creative Commons licence, unless indicated otherwise in a credit line to the material. If material is not included in the article's Creative Commons licence and your intended use is not permitted by statutory regulation or exceeds the permitted use, you will need to obtain permission directly from the copyright holder. To view a copy of this licence, visit http://creativecommons.org/licenses/by/4.0/ The Creative Commons Public Domain Dedication waiver (http://creativecommons.org/publicdomain/zero/1.0/) applies to the data made available in this article, unless otherwise stated in a credit line to the data. 